\title{
Documenting Abilities And Achievements: The Use Of Professional Portfolios For Accounting Students And Young Accounting Professionals
}

Jennifer M. Niece, (Email: jniece@assumption.edu), Assumption College

Cheryl A. Amantea, (Email: amanteapoppers@cox.net), Assumption College

\begin{abstract}
Requiring students to develop portfolios as part of the educational process is a common technique that is utilized by educators who teach various subjects from kindergarten through graduate school. Collecting course assignments and projects into a portfolio helps students see the development of their skills as they progress through school toward graduation.
\end{abstract}

Portfolio development is prevalent in certain majors - such as art and education - as well as in certain professions - such as marketing and communication. While portfolios are not typically utilized in the profession of Accounting, there are many benefits to requiring that undergraduate Accounting majors track their educational progress with a portfolio. Doing so will allow Accounting majors to understand their learning more - make it less cerebral and more recognizable. Portfolios will also assist the Accounting major to achieve entry-level professional employment.

\section{Introduction}

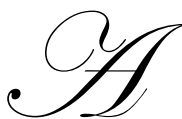

portfolio is a collection of an individual's selected work representing an array of performance. By definition, it is a self-collected, self-reported compendium of one's work. Portfolios are a dynamic way of organizing and documenting accomplishments and showcasing credentials, experiences, special talents, or skills. An effective portfolio should demonstrate achievements as well as document the scope and quality of one's abilities.

In the learning process, a portfolio allows both the student and the educator to review the development of a student's skills. Projects from a college student's freshman year will be less developed and sophisticated when compared to projects from the same student's senior year. Reviewing their work from their lower level courses and contrasting it with their senior-level work will allow the student to see just "how far they've come" as they have progressed through college. Because of the natural advancement of one's abilities as they complete more and more college courses, accounting students should be instructed to keep all of their projects and course work for possible inclusion in their portfolio. When they become juniors and seniors, they can review some of their work from the lower level courses and upgrade it for their senior-level portfolio.

It should be noted that many colleges that require student portfolio development also require a senior-level "exit interview" where the student presents and explains the portfolio to faculty members and/or other students. Oftentimes, this portfolio presentation is part of an advanced course or capstone course or possibly related to an internship or experiential learning course. 
Since the Accounting major is a "professional studies" program, the content and presentation of Accounting courses are based on what the profession is demanding currently and in the near future. Accounting courses are "industry-focused" and a recent college graduate with an Accounting degree and a portfolio will likely perform better on employment interviews as compared to a student with similar abilities but no portfolio. The reason for this is the fact that a student with a portfolio can show a prospective employer what he or she can do rather than merely tell them about their abilities. The presence of the portfolio gives the student confidence and adds structure to the employment interview.

\section{Modern-Day Portfolios}

The word "portfolio" conjures up the image of "hard copies" of someone's artwork or other projects that are visual in nature. In reality, however, many portfolio items are not "overly visual" in terms of colors and graphics. A writer's portfolio, for instance, might involve plain, unembellished text documents.

Further, the word "portfolio" conjures up the image of someone's work included in a black zippered presentation case. Higher tech versions of this old-fashioned portfolio are very common today. Typically, a professional might have his/her collection of work on a floppy disk or CD-ROM which is mailed to prospective employers, demonstrated at an employment interview, or left after an interview. Many people are also creating personal web sites and directing prospective employers to view their work online.

\section{The Development Process for Student Portfolios}

Ideally, a college student should be able to produce three items per school year that are worthy of inclusion in the portfolio. Thus, the student should have at least a dozen portfolio items upon graduation. A portfolio item might include one document or several. For example, an eight-page solution to an Accounting case study might be one item. To demonstrate the use of Excel software, however, the student might include two or three separate documents and make this into one portfolio item.

Because of the number and scope of assignments and projects that might be deemed "portfolio worthy," it is suggested that the Accounting faculty work as a team. From the introductory Accounting course onward, each faculty member should periodically discuss in class how an assignment might be included in a student's portfolio. Faculty should also collect samples of student work to demonstrate what a portfolio item entails.

Faculty input and involvement from the earliest stage of the idea of student portfolios is of paramount importance to the success of the process. If only one or two faculty members participate in the process, students are likely to not have enough items to include in their portfolios. Additionally, some intrepid faculty members might want to review their course assignments and may need to alter them so that they are more oriented to being included in a student's portfolio.

Accounting faculty should also approach the faculty in other courses and talk to them about the Accounting major's portfolio. Today, industry in general places a very high value on communication skills. Faculty members teaching English or a writing-intensive course could help direct the Accounting students to include this type of work in their portfolios as well.

Accounting faculty should also work with their college's academic computer lab staff. Lab computers are already loaded with the pertinent software utilized in Accounting courses. These computers might also be loaded with software not used in class per se but possibly used by the Accounting profession in general, such as Peachtree. Students could thus go to the academic computer lab and become familiar with other software products. Determined students will learn the basics of these computer programs and might even be able to produce a basic portfolio item from them. 


\section{What Is/Is Not Included in a Portfolio}

For the most part, a portfolio should include items that the student actually created or prepared. Letters of recommendations, award certificates, and newspaper articles written about the student should not be included.

There are a few exceptions to these general rules, however. For example, legal certification would be included in a professional's portfolio. An educator's state certified teaching license is an essential portfolio item because they must present the license during the interview process.

With some qualifying background explanation, printed collateral pieces from a student's previous or current employer are allowed as part of the student's portfolio. In order to demonstrate the size of one's employer or the demands of the level of one's work - a student might include an employer's annual report or some basic marketing-oriented materials. These items are used to explain some of the background information of the employer rather than the student's actual Accounting skills.

Graded projects are also not included in a portfolio. The student should make the corrections or improvements that were suggested by the instructor and upgrade the work accordingly.

\section{How to Utilize a Portfolio}

Portfolios are most effective when the owner of the portfolio is present to display and explain the work. Therefore, it is better that the student bring the portfolio (hard copy or disk/CD-ROM version) to the job interview, show some of the work, and explain it to the interviewer. This allows the student to show - rather than tell - the employer what he or she can do. Consequently, the portfolio should highlight the skills that employers are seeking. In the Accounting profession an emphasis is placed on communication (both written and verbal), teamwork, problem-solving, and analytical abilities.

Informative captions and short explanations might be added to the electronic version of the portfolio. That way, the employer can look at the work without the person being present. Obviously, this is not as dynamic as an animated individual proudly explaining the work in person. Since there are numerous Accounting software products in use by the profession, there is also the problem that an employer will not be able to access the disk/CD of someone's portfolio. Work done on Peachtree software, for instance, will obviously be inaccessible if an employer does not have Peachtree loaded on their computers. Therefore, work created in standard spreadsheet, presentation, and database software, such as the Microsoft Office suite, will be an important part of the portfolio so the student is not limited to a specific Accounting software.

\section{Accounting-Oriented Portfolio Items}

Here are some suggestions for portfolio items that are Accounting-oriented in nature:

- $\quad$ Excel spreadsheets and graphs representing financial statements and performance that reveal the ability to create formulas and templates as well as visually represent the numbers to enhance communication.

- $\quad$ Database project that includes the creation of a database as well as the generation of forms and reports.

- $\quad$ Sample tax return created using tax preparation software indicating the ability to use such software and its importance in the electronic filing of tax returns.

- $\quad$ Research project that utilized the Accounting journals and databases that are required for the new application components of the Certified Public Accountant (CPA) exam.

- Two or three writing samples to demonstrate business writing skills in addition to spelling, punctuation, and grammar skills along with a general command of the English language. For example, a memo assignment that required the student to summarize and communicate recommendations to management and/or clients would be appropriate.

- $\quad$ Presentation in PowerPoint of a case study used to identify and address a company's needs and resolve problems.

- $\quad$ Projects from courses that have a separate lab component to teach technical skills such as general ledger or auditing software as well as the accompanying data analysis. 


\section{Non-Accounting Portfolio Items}

An Accounting student is not limited to including only Accounting project work in his or her portfolio. Here are some other portfolio items that are not Accounting-oriented:

- Project work from courses other than Accounting courses will give the student a more "well-rounded" image. These include projects from various liberal art courses and may demonstrate such skills as writing, argument and persuasion, simple graphic design, or the use of communication-oriented software such as Publisher or Dream Weaver.

- Collateral materials from a past or current employer to demonstrate the level of professionalism of a student's work history.

- Collateral materials from a local nonprofit organization at which the student volunteered or participated in a community service learning endeavor. These materials help the student to explain more effectively what he or she did, and it is an improvement over the standard, nondescript resume item.

- Collateral materials from a student club or extracurricular activity. These are included to help the student demonstrate that he or she is well-rounded or possesses leadership abilities. It makes the student more dynamic instead of merely a two-dimensional resume listing that may or may not get mentioned during the interview process.

Furthermore, when choosing items for the portfolio, a student should include a mix of both individual projects and teamwork. Employers in the business world are seeking those students who can work well and communicate with others. Being able to demonstrate experience in a team environment is essential.

\section{Other Benefits of Portfolio Development for Accounting Students}

- $\quad$ The members of the admissions department of the college will likely find the portfolios of Accounting students useful when they promote the school and its Accounting major to prospective students and their parents.

- The Accounting faculty will find the portfolios useful when explaining and promoting the major to interested students who are already enrolled at the college and are considering Accounting as a possible major.

- $\quad$ The members of the career development department of the college will also find the portfolios of Accounting students helpful. The career development professionals might be able to attract new and different employers to participate in the college's career day or on-campus recruiting process by having a ready-made display of high level student work.

- $\quad$ The Accounting faculty might be able to use their students' portfolios to assess teaching outcomes as part of their program's or school's accreditation or re-accreditation. To illustrate, consider the assessment of the outcome of "ethics."

The Accounting major is a "professional studies" program that is based on the current practices of the Accounting profession. Ethics and the demonstrated use of ethical principles are tantamount in importance for both Accounting students and Accounting professionals. Case study solutions that deal with ethics are important to include in a student's portfolio. Other options might involve an assignment that demonstrates a practice that is considered ethical by the profession's current standards and then altering the practice so that it is unethical by standards.

The Accounting faculty could then review student portfolios to demonstrate that the students possess knowledge and understanding of ethical Accounting practices. If the Accounting major is large, the faculty could randomly select every " $\mathrm{X}$ " number portfolio to review. If the major is small, the faculty could review all of the student portfolios, or have students complete a questionnaire and review only those that state that they include a project that emphasized ethical practices. 
- $\quad$ Student portfolios also help students show other students the work required in a particular course by a particular professor. In this case, the portfolios help foster "student to student" learning.

- $\quad$ Finally, and most importantly, Accounting students will find their portfolios to be an important dimension of their Accounting education. A portfolio that includes four years' worth of work will demonstrate clearly to its owner the progress made during college education. Rudimentary freshman abilities will become polished senior-level skills. This will give the soon-to-graduate Accounting major a sense of achievement.

What's more, the portfolio will give the Accounting student an air of confidence and professionalism when the search for post-college employment commences. As the young Accounting professional's career develops and skills begin to advance, the Accounting graduate will be able to rely less on the Accounting portfolio. However, the practice of documenting one's work is always a good behavior - and it is an important one for the Accounting profession.

Ultimately then, a portfolio for the undergraduate Accounting major is likely to lead to a more sophisticated young Accounting professional.

\section{References}

1. American Institute of Certified Public Accountants. [Online]. AICPA Core Competency Framework for Entry into the Accounting Profession. Available: http://www.aicpa.org/edu/corecomp.htm

2. Bearden, Ingram, and LaForge (2004). Marketing: Principles and Perspectives. New York: McGraw-Hill, 2004.

3. Building Your College Portfolio - Kennesaw State University. [Online]. Available: http://ksumail. kennesaw.edu/ jdominic/fyeport.htm

4. Christensen, David and David Ross. [Online]. Communication Skills Needed By Entry-Level Accountants. Available: http://www.aicpa.org/members/div/career/edu/index.htm

5. Grace, Cathy et al (1998). The Portfolio Book - A Step by Step Guide for Teachers. Beltsville, MD: Gryphon House, 1998.

6. Knight, Michael E. and Denise Gallaro (1994). Portfolio Assessment. Lanham, MD: Rowman \& Littlefield, 1998.

7. Robert Half International Inc. (2003). Next Generation Accountant: New Competencies, Converging Disciplines, Expanding Roles. Menlo Park, CA: Robert Half International Inc., 2003.

8. Student Portfolios - Ursinus College. [Online]. Avalilable: http://www.ursinus.edu/Section/ StudentPortfolios/PortfolioHome.asp\#top

9. Wyatt III, Robert L. and Looper, Sandra (2003). So You Have to Have a Portfolio : A Teacher's Guide to Preparation and Presentation. Thousand Oaks, California: Corwin Press, 2003. 
Notes 